\title{
Integrated analysis of geofiltrational parameters in the context of underground coal gasification relying upon calculations and modeling
}

\author{
Oleksandr Inkin $^{1 *}$, Volodymyr Tishkov ${ }^{1}$, Nataliia Dereviahina ${ }^{1}$, and Vadym Sotskov ${ }^{2}$ \\ ${ }^{1}$ National Mining University, Department of Hydrogeology and Engineering Geology, \\ 19 Yavornytskoho Ave., 49005 Dnipro, Ukraine \\ ${ }^{2}$ National Mining University, Department of Underground Mining, 19 Yavornytskoho Ave., 49005 \\ Dnipro, Ukraine
}

\begin{abstract}
Objective of the paper is to substantiate and implement the integrated approach aimed at the studies of filtration and mass-transfer processes within roof rocks of coal seams in the context of their underground gasification. Integrity of the studies is substantiated by the use of analytical calculations as well as physical and numerical modeling. Zones with different permeability have been determined and values of specific water inflow have been identified basing upon the performed numerical modeling and involving multicomponent transformations within roof formation. The research data actuality is in the studies of spatial and temporal dynamics of rock technogenic rock permeability above gasification channel depending upon their geological structure which will favour the substantiation of efficient engineering solutions to control a process of underground coal gasification under difficult hydrogeological conditions.
\end{abstract}

\section{Introduction}

Underground coal gasification (UCG) is the method owing to which both coal mining and its processing takes one stage. The technology is a process when coal seams, considered as unprofitable for open-pit mining and underground mining, can be transformed into combustible gas to be used in the form of fuel, to generate electrical energy and to be used as chemical raw material with the help of wells. The UCG technology application relies upon a wide range of engineering and interfacing disciplines intended to provide stable process of coal seams gasification.

The paper represents integrated studies of filtration and migration processes within roof rocks of a coal seam in the context of its gasification taking into consideration the effect of temperature capabilities of the coal under gasification and rocks, enclosing them, as well as geomechanical and hydrogeological characteristics; moreover, technological conditions of gas generator operation are also involved. Integrity and multifactor nature of the processes under consideration determine a sequence of the approach to the research structure [1 -4$]$.

\footnotetext{
*Corresponding author: inkin@ua.fm
} 


\section{Analytical approach to study temperature field distribution within rock mass during underground coal gasification (UCG)}

It is known that modes of conductive and convective rock mass heating may arise within underground gas generator in terms of different underground water pressure-gas pressure ratios. Consider a situation when pressure within gas generator is less than water pressure; thus, gas effusion doesn't originate and heat transfer is of conductive nature, mass transfer with surrounding rock mass is minimal being carried out at the expense of diffusion.

In terms of static position of two rock mass phases (i.e. rock + water), thermal flow from gas generator may be reduced to axisymmetrical consideration of temperature field described by an equation of the type [5]:

$$
\begin{aligned}
& T(r, t)-T_{0}=\frac{q}{\lambda} R_{2}\left\{\frac{R_{2}^{2}}{R_{2}^{2}-R_{1}^{2}}\left[2 \frac{a t}{R_{2}^{2}}-\frac{1}{4}\left(1-2 \frac{r^{2}}{R_{2}^{2}}\right)-\frac{R_{1}^{2}}{R_{2}^{2}}\left(\ln \frac{r}{R_{1}}+\frac{R_{2}^{2}}{R_{2}^{2}-R_{1}^{2}} \ln \frac{R_{1}}{R_{2}}+\frac{3}{4}\right)\right]+\right. \\
& \left.+\sum_{n=1}^{\infty} \frac{\pi}{\mu_{n}} \frac{I_{1}\left(\mu_{n} \frac{R_{1}}{R_{2}}\right) I_{1}\left(\mu_{n}\right)}{I_{1}\left(\mu_{n} \frac{R_{1}}{R_{2}}\right) I_{1}\left(\mu_{n}\right)} \cdot\left[I_{0}\left(\mu_{n} \frac{r}{R_{2}}\right) Y_{1}\left(\mu_{n} \frac{R_{1}}{R_{2}}\right)-Y_{0}\left(\mu_{n} \frac{r}{R_{2}}\right) I_{1}\left(\mu_{n} \frac{R_{1}}{R_{2}}\right)\right] \cdot e^{-\mu_{n}^{2} \frac{a t}{R_{2}^{2}}}\right\},
\end{aligned}
$$

where $q$ is specific heat flow capacity; $R_{1}$ and $R_{2}$ are radius of a gas generator radius and its depth relative to earth's surface respectively; $r$ is distance from the gas generator axis to a reference point; $t$ is time baseline period; $T_{0}$ is background rock mass temperature; $\mu_{n}$ are characteristic first-order numbers of Bessel function for boundary values $R_{1}$ and $R_{2} ; \lambda$ is heat conductivity factor of water-saturated rock mass.

Heat-transfer problem considering relative displacement of one of the rock mass phases in the context of analytical version is extremely difficult.

One-dimensional solution in terms of finite differences for static case and taking into consideration liquid phase transfer is represented by means of the equations:

$$
\begin{gathered}
T_{i}^{t}=\frac{1}{2+\frac{\Delta x^{2}}{a \Delta t}} T_{i-1}^{t}+\frac{1}{2+\frac{\Delta x^{2}}{a \Delta t}} T_{i+1}^{t}+\frac{\Delta x^{2}}{2 a \Delta t} T_{i}^{t-\partial t} ; \\
T_{i}^{t}=\frac{\frac{\lambda}{\Delta x^{2}}-\frac{C_{w} V_{w}}{\Delta x}}{\frac{C_{r}}{\Delta t}-\frac{C_{w} V_{w}}{\Delta x}+\frac{2 \lambda}{\Delta x^{2}}} T_{i+1}^{t}+\frac{\frac{\lambda}{\Delta x^{2}}}{\frac{C_{r}}{\Delta t}-\frac{C_{w} V_{w}}{\Delta x}+\frac{2 \lambda}{\Delta x^{2}}} T_{i-1}^{t}+\frac{\frac{C_{r}}{\Delta t}}{\frac{C_{r}}{\Delta t}-\frac{C_{w} V_{w}}{\Delta x}+\frac{2 \lambda}{\Delta x^{2}}} T_{i}^{t-\Delta t,}
\end{gathered}
$$

where $a$ is temperature conductivity coefficient; $C r$ and $C w$ are heating capacities of rock and water respectively; and $V w$ is actual velocity of water flow; the mentioned specifications have already been involved.

To use the solutions correctly, certain features of the set problem should be mentioned.

Nonlinear temperature within axisymmetrical thermal flow is: temperature gradients decay at the distance of $3-4$ radii of a thermal source reduced to a cylindrical form. In the context of the layer, practical evaluations can not involve difference between onedimensional and axisymmetrical flows.

Formula (1) is true for boundary second-type conditions when a function of a heat flow is known. In terms of sensible temperature difference between thermal source $\left(T_{s}\right)$ and absorptive medium $\left(T_{0}\right)$, the function becomes constant: 


$$
q=\sigma \cdot C\left(T_{s}-T_{0}\right)
$$

where $\sigma$ is Stefan-Boltzmann constant; $C$ is a coefficient depending upon capability of the medium to absorb thermal energy.

Underground gas generator emits thermal flow which temperature achieves $1000^{\circ} \mathrm{C}$; as a rule, it means that condition (4) has been applied. It is obvious that within rock masses, being typical for coal deposits, a value of thermal flow according to condition (4) can be obtained from equation (1) on the experimental temperature measurements. To do that, use actual data from [6].

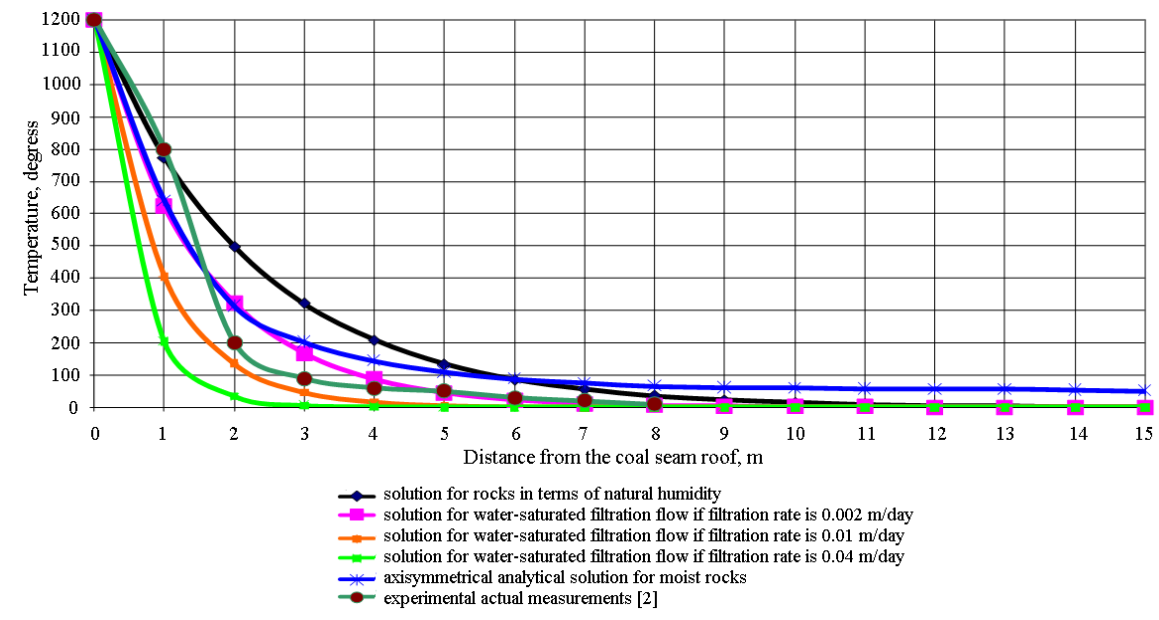

Fig. 1. Demonstrates results of variants calculations showing dynamics of temperature field within roof rocks of underground gas generator.

Results of variant calculations of dynamics of a temperature field in roof rocks of an underground gas-generator, confirmed by convergence with the actual data [6] create a possibility to evaluate the influence of hydrogeological conditions on it more differentially. The highest temperature distribution indexes in a five-meter contour are typical for a condition of rocks at natural humidity, i.e. when a massif is pre-drained. The smallest range of distribution of a temperature field is typical for conditions of water-saturated filtration flow at a filtration rate of $0.4 \mathrm{~m} /$ day, which is typical for location of sandstone rocks in a roof of a gas-generator. The study of distribution of a temperature field allows applying accurate corrections to change in physical and mechanical properties of rocks when creating numerical mathematical models.

\section{Experimental procedure and results of the experiments in the context of physical modeling}

Experimental module to study a process of distribution of temperature field of overburden rocks and their permeability (Fig. 2) was developed and manufactured taking into consideration the calculated similarity coefficients. Modeling of coal seam degassing process was performed within clear thermal-resistant tube with $1 \mathrm{~m}$ length and $0.04 \mathrm{~m}$ diameter. Compressor was used to supply air into combustion chamber. Air consumption was similar during the whole experiment. Pressure difference was recorded with the help of a manometer; temperature was recorded with the help of microthermocouple elements. 
Temperature within a medium being modeled (i.e. fine sand) was controlled from a combustion zone to combustion products extracted to atmosphere through a hydroseal. Gas consumption was recorded with the help of flow rate meter.

Source excess pressure providing air supply while igniting, was $1.013 \cdot 10^{5} \mathrm{~Pa}$. The ignition was provided by means of thermal heat of coal. After the coal started firing, the ignition device removed and combustion rate was supported with the help of air supply. After filtration, the gas was extracted through a hydroseal to the atmosphere [7].

The experiment involved visual observation of changes in the state of the coal seam and overburden rocks. Its period was limited by time of coal combustion (i.e. $45 \mathrm{~min}$ ); then the medium, which has already been saturated by gasification products, is ejected from the thermal-resistant tube for the analysis of filtration properties.

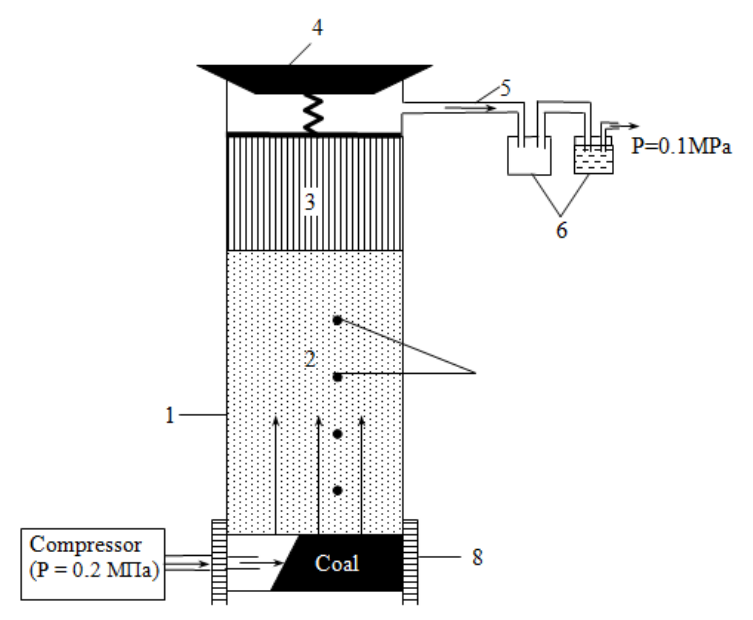

Fig. 2. Scheme of experimental facilities: 1 - clear thermal-resistant tube; 2 - roof rock of a coal seam (sand); 3 - laboratory cotton; 4 - a stopper; 5 - interconnector; 6 - moisture collector and hydroseal; 7 - thermocouple elements; and 8 -ignition device.

To evaluate filtration parameters of the medium, its particle composition was studied with the help of grain-size analysis. Since effective diameter is 0.1 to $3 \mathrm{~mm}$ and heterogeneity coefficient is less than 5, nomogram of N.N. Bindeman has been applied to determine a filtration coefficient of the medium being modeled [8]. A value of the filtration coefficient was $k_{f}=3 \mathrm{~m} /$ day. Permeability coefficient $k_{p}$ has been identified according to the dependence [9]:

$$
k_{p}=\frac{k_{f} \cdot \mu}{\rho \cdot g},
$$

where $k_{f}$ is filtration coefficient; $\mu$ and $\rho$ are dynamic viscosity and water density. The calculated value of sand permeability within the experimental facilities was determined as $4.46 \cdot 10^{-11} \mathrm{~m}^{2}$.

Permeability coefficient was also evaluated according to data obtained during the experiment relying upon formula (6) [10]:

$$
\kappa_{p}=\frac{2 \mu P_{a t} Q L}{F\left(P_{1}^{2}-P_{2}^{2}\right)},
$$

where $P_{a t}$ is atmospheric pressure $\left(1.013 \cdot 10^{5} \mathrm{~Pa}\right) ; Q$ is consumption of air being pumped to a combustion chamber $\left(4 \cdot 10^{-5} \mathrm{~m}^{3} / \mathrm{s} ; L\right.$ and $F$ are a seam thickness and sectional area of 
overburden rocks $\left(0.5 \mathrm{~m}\right.$ and $\left.1.25 \cdot 10^{-3} \mathrm{~m}^{2}\right) ; \mu$ is average dynamic viscosity of filtering gas $\left(1.481 \cdot 10^{-5} \mathrm{~Pa} \cdot \mathrm{s}\right)$; and $P_{1}$, and $\mathrm{P}_{2}$ are intake pressure and output pressure on the exit from a layer of gas-permeable rocks respectively $\left(2.026 \cdot 10^{5} \mathrm{~Pa}\right.$ and $\left.1.013 \cdot 10^{5} \mathrm{~Pa}\right)$.

The $k_{p}$ value, determined on (6), was $3 \cdot 10^{-12} \mathrm{~m}^{2}$. Difference between the obtained values of permeability coefficient is allowable taking into consideration empiric data of granular sand composition. The obtained experimental value should be used in the context of subsequent calculations.

In the course of the experiment, temperature was recorded in certain points of the model at the distances of 5, 10, 12, 15 and $20 \mathrm{~cm}$ from the combustion source. The temperature was recorded continuously with the help of identical thermal couples connected to multichannel recorder H-307. The thermal couples have been calibrated relative to hyperthermal temperature gauge TG-31A No. 433 with $\pm 2{ }^{\circ} \mathrm{C}$ error. Fig. 3 and 4 demonstrate over-time temperature variations within the filtering medium.

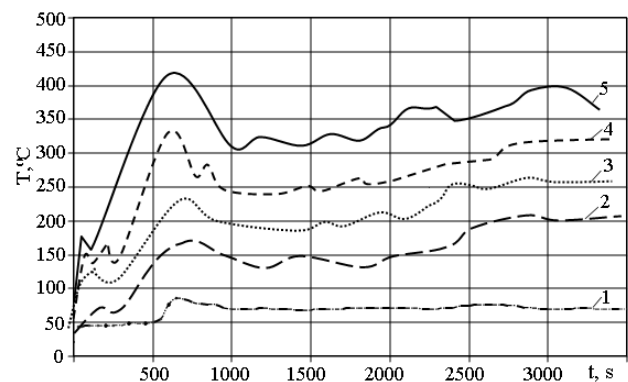

Fig. 3. Temperature variations within the filtering medium: 1, 2, 3, 4 and 5 are temperature variations in a roof at the distance of $20,15,12$, 10 and $5 \mathrm{~cm}$ from the top edge of the combustion zone respectively.

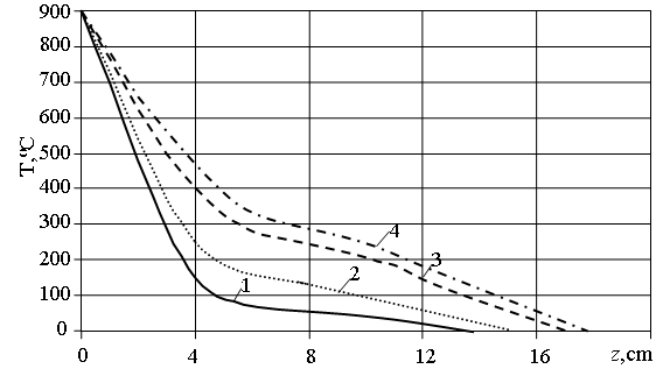

Fig. 4. Heating intensity of overburden rocks: 1, 2, 3 , and 4 are temperature distribution within a roof after 200, 400, 600 and $2500 \mathrm{~s}$ from the experiment beginning respectively.

The coal seam state as well as overburden rocks state was observed visually synchronous with temperature recordation; as a result, the following was determined:

- a zone of coal combustion is convex towards air motion; its geometry depends upon a supply rate;

- combustion zone-overburden rocks contact is unstable; overlying sand material penetrates into the combustion zone;

- in due course, the filtering medium (i.e. sand material) becomes grey with point distribution of black microinclusions;

- through the microscope, films of resinous substances, thickening within irregularities, are seen at the surface of the sand grains;

- an arch is formed right above the zone of coal combustion; its stability depends upon the number of carboniferous inclusions and dimensions of the zone is determined with the help of the coal-combustion process duration.

The data, obtained during the experiments, have helped conclude that rocks of immediate roof, occurring closer to the combustion zone, become of higher temperature and start varying first. Temperature increase within overburden rocks is followed by changes in their physical and mechanical characteristics. After rock heating, evaporation of natural and bound moisture starts. The evaporation originates at the temperature of $100{ }^{\circ} \mathrm{C}$; when the temperature achieves $200{ }^{\circ} \mathrm{C}$ and exceeds it, chemical moisture is liberated from roof rocks. Temperature increase up to $600{ }^{\circ} \mathrm{C}$ results in agglomeration and further decomposition of certain elements of overburden rocks (Fig. 5). 

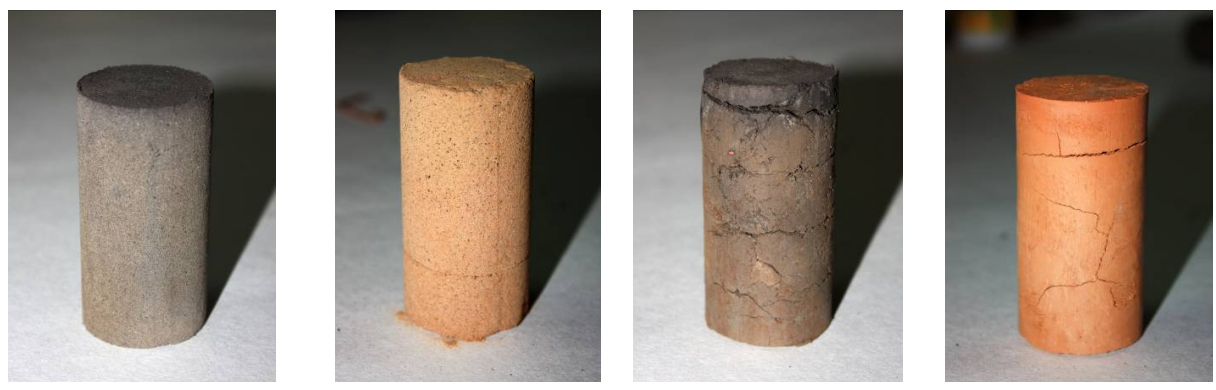

Fig. 5. Samples of sandy deposits and argillaceous deposits of Dniprobas after 400 and $650{ }^{\circ} \mathrm{C}$ temperature field effect on rock mass.

Analysis of curves (Fig. 2 and 3) means that roof rock heating process is intensive during the first 600 seconds from coal ignition within a combustion zone. Further heat transfer is a very slow process. The phenomenon can be explained by the fact of the decreased thermal conductivity of overburden rocks at the expense of changes taking place in their physical state (i.e. agglomeration, expansion, pore mudding) under the effect of high temperature and chemical effect of escaping gas. Insignificant temperature variations during the experiment can be explained by the unstable burning process and, consequently, temperature fluctuations within inlet boundary.

In the context of the medium, being modeled, vertical temperature distribution is nonlinear process. Distribution of temperature within certain areas (see Fig. 3) corresponds to the processes of rock variations, condensation of filtering gas, and circulation of gas flows with constant temperature.

Both physical and filtration properties of the medium, saturated during the experiment, were calculated and determined from its different areas by means of a technique of cutting cylinders [11]; Table 1 contains the results.

Table 1. Structure and properties of overburden rocks saturated by gasification products (according to the data of physical modeling).

\begin{tabular}{|c|c|c|c|c|c|}
\hline$\stackrel{\Xi}{0}$ & $\begin{array}{c}\text { Distance } \\
\text { from a } \\
\text { coal } \\
\text { seam } \\
\text { roof, m }\end{array}$ & Prevailing processes & 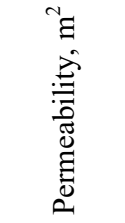 & 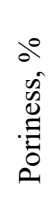 & 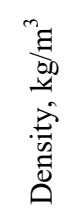 \\
\hline 3 & $>2.5$ & Filtration gas flow (undisturbed rocks) & $3 \cdot 10^{-12}$ & 33 & 1510 \\
\hline 2 & $0.5-2.5$ & $\begin{array}{l}\text { Filtering gas condensation (pores are filled with } \\
\text { liquid carbohydrates) }\end{array}$ & $1.6 \cdot 10^{-12}$ & 27 & 1630 \\
\hline 1 & $<0.5$ & $\begin{array}{l}\text { Rock melting (slagged and agglomerated rock } \\
\text { with the inclusion of unburnt combustibles) }\end{array}$ & $9.2 \cdot 10^{-13}$ & 21 & 1740 \\
\hline
\end{tabular}

The analysis shows that migration of gasification products (GP) within filtering medium results in nonuniform filling of pore space with the formation of several zones. First of all, GP distribution depends upon temperature distribution. Poriness of overburden rocks and their permeability vary owing to mechanical blocking of pores by means of unburnt combustibles as well as physical and chemical GP-rock interaction. A zone of thermally altered rocks with solid carboniferous inclusions is the closest to the degassed area. In consideration of geometrical similarity coefficient $\left(C_{1}=25\right)$, thickness of the zone will not be 
more than $0.5 \mathrm{~m}$ under full-scale conditions. Above the zone (at the distance of $0.5-2.5 \mathrm{~m}$ ) a condensation zone is located which porous space is filled with resinous products. Within the overlying zone of undisturbed rocks, constant-temperature gas flows circulate.

The determined regularities coincide qualitatively with the data obtained at Shahtinsk station "Pidzemhaz" $[12,13]$. Thus, after gasification of a coal seam "Rozovyi" with $0.4 \mathrm{~m}$ thickness, upper share of overburden rocks was melted layer containing unburnt combustibles with up to $20 \mathrm{~cm}$ thickness. Above the layer (at the distance of $0.2-1.5 \mathrm{~m}$ ) rocks transferred gradually from melted (i.e. red colour) to undisturbed (deep blue ones). Temperature above the layer being characterized was $700-800{ }^{\circ} \mathrm{C}$; it dropped gradually down to $500{ }^{\circ} \mathrm{C}$. Then, the temperature became $150-200{ }^{\circ} \mathrm{C}$ within a zone where the rocks transferred from heat-dried state to water-saturated one.

Zones of immediate roof annealing of "Rozovyi" coal seam were located closer to a rock boundary of the underground gas generator to compare with the zones selected for the experiment. Their eliminating can be explained by slower decrease in the parameters of gas being filtered within the medium under modeling (sand material) and, consequently, by its greater permeability and heat transfer to compare with "Rozovyi" seam roof (shale).

\section{Numerical modeling of filtration parameters in the context of two-layer rock formation within a roof of a gas generator}

If a coal seam roof contains water-proof argillaceous rocks (even with carbonaceous component) and up to $0.01 \mathrm{~m} /$ day values of filtration coefficient being typical for them (Fig. 5), the values of specific water inflow in the context of shear deformations of the rock formation $[14,15]$ are within $0.11-0.23 \mathrm{~m}^{2} /$ day when gas generator operates.

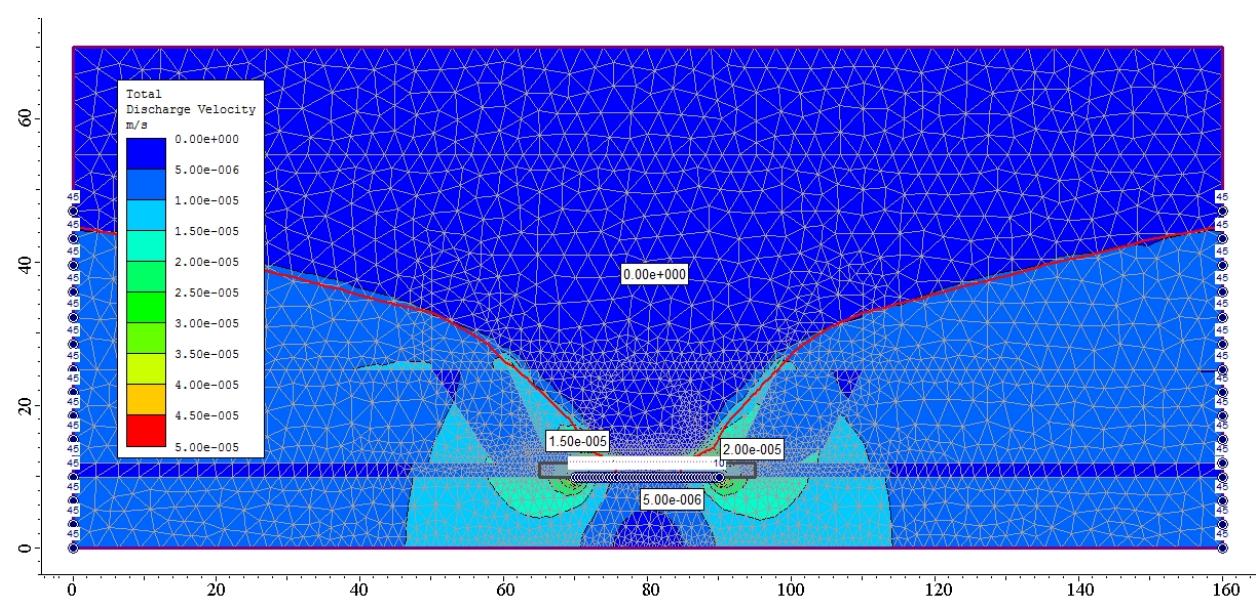

Fig. 5. Distribution of filtration rates within foliated rock mass disturbed by operation of the gas generator if waterproof layer is available within a roof of a coal seam, $\mathrm{m} / \mathrm{s}$.

The evaluation of changes in hydrodynamic mode of the complicated rock formation, containing gas generator, has shown that formation of filtration parameters depends directly on the changes in rock lithology under the effect of temperature field, geomechanical processes, and residual hydraulic pressure.

On the basis of numerical simulation, under conditions of a complex lithological structure of roof rocks $[16,17]$, it is possible to determine the values of specific water inflows into the channel of a gas-generator at various stages of its formation with sufficient 
accuracy. The solution of this problem is possible only with a complex approach based on previously obtained data on the transformation of physical and mechanical properties of rocks under the influence of temperatures, and a change of geofiltration parameters in a geomechanically disturbed massif.

\section{Conclusions}

It is established that the zone of intensive thermal transformation of rocks reaches $2.5 \mathrm{~m}$, which is confirmed by the results of physical simulation. The decrease of the temperature field to $100^{\circ} \mathrm{C}$ occurs in an interval from 1.5 to $4.5 \mathrm{~m}$, and is non-linearly distributed vertically. These patterns coincide qualitatively with the data obtained at Shakhtynska station of "Pidzemhaz".

The temperature increase in covering rocks is accompanied by a change in their physical and mechanical characteristics. Evaporation of natural and bound water begins after the warming of rocks. At a temperature above $200{ }^{\circ} \mathrm{C}$, the release of chemical moisture from the roof rocks begins, and a temperature increase to $600{ }^{\circ} \mathrm{C}$ leads to sintering and further disintegration of individual components of covering rocks and a change in their permeability.

The physical modeling results have helped determine permeability coefficient for different roof zones above gasification channel. Difference between the obtained values of the permeability coefficient is allowable on the basis of granular sand composition.

Zones with different permeability have been determined and values of specific water inflow have been identified basing upon the performed numerical modeling and involving multicomponent transformations within roof formation.

Publications are based on the research provided by the grant support of the State Fund For Fundamental Research (project No. 54918).

\section{References}

1. Nourozieh, H., Kariznovi, M., Chen, Z., \& Abedi, J. (2010). Simulation Study of Underground Coal Gasification in Alberta Reservoirs: Geological Structure and Process Modeling. Energy Fuels, 24(6), 3540-3550. https://doi:10.1021/ef9013828

2. Otto, C., \& Kempka, T. (2017). Prediction of Steam Jacket Dynamics and Water Balances in Underground Coal. Gasification Energies, 10(6), 739.

3. Lykov, A.V. (1952). Teoriya teploprovodnosti. Moskva: Gostekhteoretizdat.

4. Pivnyak, G., Dychkovskyi, R., Bobyliov, O., Cabana, E., \& Smoliński, A. (2018). Mathematical and Geomechanical Model in Physical and Chemical Processes of Underground Coal Gasification. Solid State Phenomena, (277), 1-16.

https://doi.org/10.4028/www.scientific.net/SSP.277.1

5. Russo, Yu.V. (1957). Teplovye poteri v bokovykh porodakh pri podzemnoy gazifikatsii tonkikh pologikh i naklonnykh kamennougol'nykh plastov. Podzemnaya gazifikatsiya ugley, (5).

6. Kreynin, Ye.V. (2004). Netraditsionnye termicheskie tekhnologii dobychi trudnoizvlekayemykh topliv: ugol', uglevodorodnoe syr'ye. Moskva: IRTS Gazprom.

7. Tishkov, V.V. (2014). Otsenka vodopritoka v kanal podzemnogo gazogeneratora pri izmenenii parametrov pronitsayemosti massiva v usloviyakh Dneprobassa. Mining of Mineral Deposits. 8(4), 409-413. https://doi.org/10.15407/mining08.04.409

8. Sadovenko, I.O., Timoshchuk, V.I., \& Tishkov, V.V. (2010). Doslidzhennia vplyvu napruzhenodeformovanoho stanu vmishchuiuchykh hirskykh porid na ikh filtratsiini vlastyvosti pry pidzemnii hazyfíkatsii vugilnykh plastiv v umovakh Dniprobasu. Naukovyi Visnyk Natsionalnoho Hirnychoho Universytetu, (3), 32-33. 
9. Sadovenko, I.A., Polyashov, A.S., \& Inkin, A.V. (2004). Eksperimental'nye issledovaniya mekhanizma fil'tratsii produktov gazifikatsii. V Materialakh Ukrainsko-Polskoho Forumu Hirnykiv (pp. 598-603).

10. Mironenko, V.A. (1983). Dinamika podzemnykh vod. Moskva: Nedra.

11. Semenenko, D.K., Russa, Yu.V., \& Ovchinikov, V.M. (1959). Gazopronitsaemost' vygazovannogo prostranstva, zapolnennogo oshlakovannymi porodami. Podzemnaya gazifikatsiya ugley, (4), 19-21.

12. Lomtadze, V.D. (1952). Metody laboratornykh issledovaniy fiziko-mekhanicheskikh svoystv peschanykh i glinistykh gruntov. Moskva: Gosgeolizdat.

13. Skafa, P.V. (1960). Podzemnaya gazifikatsiya ugley. Moskva: Gosgeolizdat.

14. Sotskov, V.O., Demchenko, Yu. I., Salli, S.V., \& Dereviahina, N.I. (2017). Optimization of parameters of overwoked mining gallery support while carrying out long-wall face workings. Naukovyi Visnyk Natsionalnoho Hirnychoho Universytetu, (6), 34-40.

15. Fomichov, V., Sotskov, V., Pochepov, V., \& Mamaikin, O. (2018). Formation of a calculation model determining optimal rate of stoping face movement with a large deformation of a rock massif. ARPN Journal of Engineering and Applied Sciences, 13(7), 23 81-2389.

16. Sotskov, V., \& Saleev, I. (2013). Investigation of the rock massif stress strain state in conditions of the drainage drift overworking. Annual Scientific-Technical Collection - Mining of Mineral Deposits, 197-202. https://doi.org/10.1201/b16354-36

17. Malashkevych, D., Sotskov V., Medyanyk V. \& Prykhodchenko D. (2018). Integrated Evaluation of the Worked-Out Area Partial Backfill Effect of Stress-Strain State of Coal-Bearing Rock Mass. Solid State Phenomena, (277), 213-220. https://doi.org/10.4028/www.scientific.net/ssp.277.213 